\title{
A utopia como atributo da educação emancipatória'
}

\section{Utopia as an attribute os emancipatory education}

\author{
José Washington de Moraes MEDEIROS² \\ Edna Gusmão de Góes BRENNAND ${ }^{3}$
}

\begin{abstract}
Resumo
Este ensaio reflete sobre ideais pedagógicos da educaçáo moderna, herdados da filosofia Iluminista, como baliza para a formação cidadá, crítica e transformadora na atualidade. Trata das bases educacionais que fundam a emancipação e a utopia e que visam concretizar a autonomia do sujeito como agente de uma sociedade livre, justa e igualitária. A discussão é subsidiada por incursos teórico-hermenêuticos como metodologia compreensivo-interpretativa, fundamentada nas categorias habermasianas de sociedade e razão, para reconhecer a educação como um fenômeno universal e permanente, que aglutinou pluralidades de perspectivas (dialéticas) que moldaram o entendimento sobre seu conceito e sua missão histórico-social.
\end{abstract}

Palavras-chave: Utopia. Racionalidade. Emancipação. Educaçáo
Abstract

This essay reflects on pedagogical ideals of modern education, inherited from the Elightenment philosophy, as a mark for the citizen, critical and transformative formation in the present. It is about the educational bases that establish emancipation and utopia, and that aim to materialize the individual's autonomy as an agent of a free, fair and egalitarian society. The discussion is subsidized by theoretical-hermeneutic incursions as comprehensive-interpretive methodology, based on the Habermasian categories of society and reason, to recognize education as an universal and permanent phenomenon that aggregated pluralities of (dialetical) perspectives which shaped the understanding about its concept and historical-social mission.

Keywords: Utopia. Rationality. Emacipation. Emancipatory

1 Este texto é parte de uma tese de Doutorado em Educação, financiada pela Capes, que visou compreender a lógica tecnicista do agir pedagógico à luz da Teoria da Ação Comunicativa de Jürgen Habermas.

2 Doutor em Educação e docente do Mestrado Profissional Em Educação Profissional e Tecnológica da Instituto Federal da Paraíba - IFPB. Lattes: http://lattes.cnpq.br/3970142119835546. Orcid: http:// orcid.org/0000-0002-7481-5902. E-mail: washi_med@yahoo.com.br

3 Doutora em Sociologia e docente do Programa d Pós-graduaçáo em Educação da Universidade Federal da Paraíba - UFPB. Lattes: http://lattes.cnpq.br/9163217527871872. Orcid: https://orcid.org/0000-00017471-3343. E-mail: ednabrennand@gmail.com 


\section{Introdução}

Há cerca de três séculos, a humanidade vem alimentando o ideal transformador da educação iluminista e o progresso humano e social por meio da evolução da ciência e da tecnologia. Sob tal égide, a liberdade deixaria de ser o afã autofantasiado pelo imaginário coletivo para se tornar realidade histórica, corolária às relações fraternas, geridas pela descentralização de mundo, pela expressividade da livre consciência e pela legitimação do pensamento racional.

Nesse contexto histórico, a educação foi pensada como "pedra angular" para a compreensão/reconstrução da realidade; como promotora da autonomia, da emancipação, da evolução social, e ganharam fôlego as concepçóes de educação como um espaço viabilizador de condições de vida mais dignas e mais qualificadas. No entanto, no início do Século XXI, grande parte das esperanças que alimentaram a educação iluminista parece que se esvaneceu nas mesmas turbulências que trouxeram "irracionalidade" para a humanidade. Distorcida e enfraquecida em suas bases filosóficas, a razão sente cada vez mais encorpada sua dimensão técnico-científica, espalhando sobre as esferas da subjetividade, da cultura e da sociedade um rastro quase inapagável, marcado pela ideologia capitalista e seus liames furtivos.

Nesse cenário, parece difícil entender como as grandes mutaçóes da contemporaneidade emergiram diante das conquistas revolucionárias, assoladas pelo aumento exponencial dos ciclos informacionais digitais e, paradoxalmente, pela debilidade na socialização da comunicação, pela desestruturação da opiniáo pública e da vontade, pela desintegração da identidade coletiva, pelo empobrecimento cultural, pelo enfraquecimento da solidariedade, bem como pelo empreendedorismo moral. Este último emergiu com força aterradora no atual momento político brasileiro.

Inspirados na re-evocação da razão e no equilíbrio das propostas do moderno pensamento pedagógico iluminista, buscamos dimensionar a contribuiçáo de algumas ideias habermasianas como parâmetros para a pedagogia contemporânea. Suas bases não se findam em modelos técnicos do conhecimento, mas inspiram fundamentos que podem enriquecer a própria filosofia da educação e fazer da linguagem náo o meio de transmitir conhecimentos, mas o lócus de reconstrução da verdade e da percepçáo de mundo - um novo espaço povoado do espírito democrático, guardador de lugar para o sentido da consciência cidadá transformadora. Em razão disso, num mundo que aglutina desigualdades e descrenças, de um lado, e acúmulo de capital e de riquezas, de outro, somos desafiados a atenuar a visibilidade das coisas por meio de teorias que fomentem 
utopias. A teoria da ação comunicativa nos forneceu elementos para que situássemos os processos educativos no centro da grande "ágora " planetária.

Assim, este texto traz elementos da teoria da ação comunicativa, acentuada pelos constructos das teorias da racionalidade e da sociedade habermasianas, para compreender a educação moderna na integração das sociedades complexas contemporâneas. Em termos metodológicos, o lugar de fala da compreensão do fenômeno fundou-se na hermenêutica de Habermas (1987) e em suas possibilidades exegéticas (interpretativas). A tarefa comunicativa da hermenêutica media a conexão entre mundos: o mundo de quem interpreta e o mundo do que se torna matriz de compreensão - o fenômeno estudado. E como a hermenêutica "[...] equivale à maneira científica do agir interpretativo do cotidiano", conforme enfatiza Habermas (1987, p. 185), trazemos esse fundamento interpretativo como base para que entendamos as aporias sobre $o$ projeto moderno da educação e, em contraponto, sua utopia como educação emancipatória, o que enseja o discurso na teia de sentidos de suas verdades e justificaçôes (HABERMAS, 2004b).

\section{A educação entre cosmovisões naturalistas e ortodoxias religiosas}

A educação, projetada como um processo gerador do futuro utópico, configura-se como amparo do pensamento moderno - a síntese gerada e geradora da razão, guardiã das expressividades lógicas, da crítica, do esclarecimento e da emancipaçáo. $\mathrm{O}$ poder reflexivo dos processos educativos deveria aumentar o poder crítico do pensamento, constantemente em progressão. Seus fundamentos encontram na validade da cultura moderna a ideia de fazer dos processos educativos o caminho para alcançar princípios racionais universais para o agir e o pensar em sociedade.

Os ideais pedagógicos da educação moderna, herdados da filosofia iluminista, intentam formar o sujeito crítico e transformador, disseminando a racionalidade como fonte do conhecimento renovado. Suas bases se fundam no esclarecimento e na libertaçáo como as duas grandes perspectivas de sua utopia, cuja atitude singular consiste em concretizar a autonomia do sujeito como agente de uma sociedade livre, justa e igualitária. Como fenômeno universal e permanente, a educação aglutinou em torno de si uma pluralidade de perspectivas que adornaram o entendimento sobre seu conceito e sua missão histórica na sociedade. No entanto, as dificuldades que os filhos da razão (da modernidade) encontraram à frente das conquistas perseverantes do que Kant (1985) chama de esclarecimento (superação 
da menoridade $)^{4}$ parecem ter neblinado o horizonte oferecido pelo uso processual da riqueza cognitiva da modernidade cultural. Em outros termos, a reconversão dos ideais utópicos da razão, esclarecedora e libertária, deslocada das próprias bases por inflamaçóes severas que trouxeram graves perdas de sentidos, desolou as propostas filosóficas do projeto moderno de mundo e abalou os grandes propósitos da Educação e os grandes axiomas da Ciência. A destituição das metanarrativas, que, até pouco tempo, davam mais "conforto" à Ciência e à compreensão de mundo, fez sucumbirem as certezas das reordenaçóes conjunturais marcadas ora por conquistas, ora por aparentes falências múltiplas de órgãos vitais para a sociedade, como a Educação.

Nesse sentido, ao mesmo tempo em que surge repleta de promessas para o exercício livre da subjetividade, a educação moderna cai na teia invisível do poder que a coloniza e passa a geri-la com manipulaçôes econômicas e políticas. Surge daí um grande paradoxo: ao mesmo tempo em que viceja no homem moderno o espírito de autonomia, decorrente da condição de "liberto" das imagens de mundo advindas da Idade Média, explodem manifestaçôes do consumismo, do conformismo e do individualismo.

$\mathrm{Na}$ proporção em que a Educação e a Ciência modernas se enriquecem com as orientaçôes de uma ética racionalmente fundamentada no sentido de universalidade, sua identidade também se torna cada vez mais frágil com a resignação a uma ordem autorregulada por forças que lhe fogem do controle. Ao se tornar instrumental, a Ciência teleguia-se como mecanismo de dominação, e a Educação passa a ser uma de suas alças mais rentáveis para reproduzir a cultura resignada, isto é, o apanágio de uma ordem social que se multiplica a partir das próprias entranhas. Seu modelo de desenvolvimento, baseado no agir economicista como gestor do capital, preza, cada vez mais, pelo saber técnico (hiper-racionalismo da razão aplicada sob a ideia de "produto final") como parâmetro de validade para se construir e apreender o conhecimento e manter, sob o foco das práticas e dos conteúdos educativos, as formas da organização empresarial e da produção industrial. Quando essa condição global não promove a fuga do eu e motiva grandes transtornos sociais, incita a radicalidade da autodestruição ou dos instintos de morte por parte do sujeito isolado, afora uma gama de patologias que se espalham nas várias esferas da cultura, da sociedade e da personalidade.

4 "Esclarecimento é a saída do homem de sua menoridade, da qual ele próprio é culpado. A menoridade é a incapacidade de fazer uso de seu entendimento sem a direção de outro indivíduo. $\mathrm{O}$ homem é o próprio culpado dessa menoridade se a causa dela não se encontra na falta de entendimento, mas na falta de decisão e coragem de servir-se de si mesmo sem a direção de ourem. Sapere aude! Tem coragem de fazer uso de seu próprio entendimento, tal é o lema do esclarecimento" (KANT, 1985, p. 100). 
O conceito de patologias sociais advém da teoria crítica da sociedade e faz referência a um contexto complexo de domínios, com o fim de deflagrar os sofrimentos sociais ocultos, propiciados pela razão instrumental, por meio dos processos de industrialização, comercialização, burocratização, controle, legalização de normas e leis, cientificação e aplicação tecnológica com açóes guiadas e interesses não coletivos. As patologias sociais são, pois, "chagas ocultas" que se envolvem, por exemplo, na marginalização social e na exclusão cultural (HABERMAS, 2004a).

Depois de passadas poucas décadas, em que a Segunda Grande Guerra asseverou a gravidade das patologias sociais e devastou o mundo, é difícil acreditar que a diferença, como característica inerente às culturas dos povos, das naçóes, das etnias, dos gêneros e das crenças, é o incremento mais crucial da divergência, fator da intolerância, da intransigência e da inconvivência. Crescem apartaçôes e discriminaçóes que alimentam conflitos étnicos, exploraçóes, perseguiçóes, crimes de ódio e disputas políticas e religiosas.

O perigo da razão mitológica está à solta nas esferas culturais da vida, substituindo conceitos como universalidade, subjetividade e autonomia por princípios opostos, como particularismo, determinismo, individualismo e fundamentalismo. No contexto da sociedade em rede, discutida por Castells (1999), práticas humanas têm a possibilidade de se reordenar, inclusive perspectivas religiosas que, em nome da fé, atraem adesóes de indivíduos cada vez mais descrentes da racionalidade, perdidos em reducionismos que particularizam seus problemas como se só fossem de ordem subjetivista.

É desse modo que as estruturas do sagrado parecem regenerar-se diante dos problemas sociais que fazem agonizar o cenário arrebatador da crise planetária. Os primeiros passos da história do Século XXI caminham ora em direção ao futuro desbravador e guiado pela utopia, devido à dessublimação dos mistérios como condiçẫo para a busca de verdades dialogáveis, ora no arcabouço de uma espécie de razão "esquizofrênica" e suas alucinações trilhadas sob os escombros de um passado de medo e seus conflitos míticos entre fé, política e ciência.

Diante disso, Habermas (2007) assevera que, no cenário cultural de nossa época, eclode o conflito de duas dimensôes de "desvios" que acarretam contornos diferentes à razão: as cosmovisöes naturalistas e as ortodoxias religiosas. Na primeira, figuram as inovaçôes, as descobertas, as experiências, os métodos e as proposiçóes com que as pesquisas genéticas (biogenética/bioética), do cérebro humano associado à informática (inteligência artificial), da nanotecnologia, da cosmologia, da robótica, dentre outras áreas, imprimem um naturalismo cientificista, uma autocompreensão objetivada da realidade e referenciada nas ciências naturais. A difusão de imagens do mundo naturalista absorve um adestramento capaz de tornar observável/experimentável a realidade e de estimular e de reduzir a 
compreensão de mundo com suposiçóes autointrumentalizadoras. Por outro lado, as cosmovisóes naturalistas também espalham na vida cotidiana o caráter de expectativas, atormentadamente esperadas por pessoas a quem a aplicação terapêutica das descobertas científicas pode servir de imediato, seja no levante de informaçóes significativas sobre novos tipos de tumores e cânceres, sobre a Aids e sobre a esclerose múltipla, por exemplo, seja na cura definitiva de outras graves doenças, assim como atenuando sofrimentos de pacientes, portadores de doenças em estágios degenerativamente sem volta.

$\mathrm{Na}$ segunda dimensão, as tradiçóes religiosas revitalizam-se com a força das comunidades de fé, aglutinadas não só com as tendências espirituais, a sensibilização e os cultos, mas também com a politização adquirida e dirigida pelas próprias tradiçóes. Diversificam-se templos de adoração que se adjetivam, formando uma aparente tipologia conglomerada, a partir das manifestaçóes autorreguladas pela própria interpretação que se constituem sobre a divindade e com a ideia de verdade. Multiplicam-se, assim, açóes de pastores, padres, mentores e consultores espirituais, sacerdotes e missionários, dentre outros agentes da fé. $\mathrm{O}$ caráter inesperado da "volta" da verdade como mistério, através da religiáo, configura, em âmbito mundial, o "reavivamento" das forças religiosas e o perigo do fundamentalismo que se espreita em certas expressóes. Isso constitui a crítica tenaz sobre o que as ortodoxias religiosas podem levantar contra a modernidade ocidental.

Habermas (2007) entende que o problema não se restringe à constatação da existência renovada do naturalismo cientificista e da ortodoxia religiosa per $s i$, mas à amplificação da discordância, como um fator que pode reduzir o acordo possível, ou seja, na oposição entre os dois polos, que parecem se digladiar no transrelacionamento e diminuir seu potencial de autorreflexão, da capacidade de respeitar a existência e os limites da fé e do saber (HABERMAS, 1997).

Diante desse quadro preocupante, cabe um exemplo singular: desde o trágico onze de setembro, nos Estados Unidos, quando houve o fato mais abissal da atualidade, o fosso histórico entre fé, política e saber afundouse ainda mais sob o espetáculo trágico da morte ao vivo. $\mathrm{O}$ mundo abalouse na tempestade da fé cega do fundamentalismo, que escancarou o terror generalizado como a mais extrema antítese da razão e, com ela, da derrota da liberdade "polissignificada". Assim, em um momento difícil para a história humana, quando manifestaçóes universalmente antivitais, como o terrorismo, resgatam e maximizam os medos de um passado de destruiçôes, surgem feiçôes inusitadas para a morte diante de inimigos ocultos, e convicçóes/expressóes religiosas erguem a bandeira da fé contra os símbolos da sociedade moderna globalizada. O conflito de convicçôes é de grande vulto em organismos sociais praticamente encarcerados em sofrimentos coletivos, por intermédio de sujeitos assolados em suas dores hiperindividualizadas. 
Explicações convincentes sobre as decorrências patológicas do mundo atual parecem escorregar da compreensáo imediata, principalmente diante das luzes proféticas com que a ideia da vida livre nutriu as esperanças dos homens no Iluminismo. No estágio atual do mundo, o indivíduo, muitas vezes, não consegue, sequer, encontrar brechas para resolver suas crises subjetivas e de identidade, situadas na mesma fervura em que ardem as chagas expostas das sociedades complexas.

Habermas (1980), entende por sociedades complexas a atual fase do sistema capitalista, quando o Estado assumiu as funçóes de coordenar os interesses econômicos e de gerir políticas que possibilitam o fortalecimento da dinâmica do capital. No capitalismo regulado pelo Estado, as contradiçóes ou crises do sistema acontecem quando são fomentadas mudanças sociais que desarticulam a ordem político-econômica (im)posta como modelo fundador. Isso significa dizer que as sociedades contemporâneas, também conhecidas como sociedades complexas, vivem um quadro de perplexidade cada vez mais difícil de ser compreendido em sua conjuntura. As profundas transformaçóes provocadas pelas crises da modernidade reordenaram as esferas da ciência, da tecnologia, da política, da economia e da cultura e provocaram grandes transtornos na personalidade, na cultura e na sociedade.

Nesse aspecto, a integração das sociedades complexas contemporâneas acontece, via de regra, por meio de três veículos de comunicação social, matizados pelo que Habermas $(2003 ; 2001 ; 1999 ; 1990)$ chama de mundo dos sistemas, um dos fatores constituintes da teoria da sociedade: a) o dinheiro, que é um mecanismo institucionalizado pelo mercado; b) o poder, que é uma entidade institucionalizada pelas organizaçóes deliberadas por políticas de proliferação monetária como germe de consolidação do próprio poder; e c) a solidariedade, um veículo distintamente praticado na contramão do dinheiro e do poder; um fenômeno gerador de mudanças cíclicas no individualismo, que faz parte de um processo evolutivo propiciado pelas normas, pelos valores e pela comunicaçáo livre (HABERMAS, 2004a).

Contextualizaçóes que justificam os lastros deixados pelos problemas da sociedade contemporânea são abundantes e não fazem parte, estritamente, do terreno educacional, uma esfera de transformaçóes, cuja ideia primeira se funda nos atributos profundos da solidariedade, sobretudo no compartilhamento de aprendizagens abertas, reflexivas, múltiplas e colaborativas com e sobre o mundo das coisas. As crises das sociedades complexas alinham-se em dimensóes tão sérias que ameaçam a dignidade humana, como, por exemplo, as causas dos fluxos migratórios internacionais e a própria existência humana, devido ao perigo iminente com que o aquecimento global já sinaliza desolar a ecologia (ecossistema), a geografia (os territórios), a história (a progressão dos tempos), 
bem como a brevidade da vida no planeta (a extinçâo dos organismos vivos).

$\mathrm{O}$ encurtamento da racionalidade ocidental moderna para uma constituição racionalista dirigida a fins (instrumental) constitui e é constituído por um prognóstico autorreferencial da individualização do $e u$, que estabelece a si mesmo o modelo de se relacionar com o mundo. Isso tem causado uma extrema desarmonia e dissipado o mundo interior $(e u)$ do seu entorno cultural e social, estrangulando a solidariedade - um dos fenômenos mais evolutivos da humanidade, fruto do envolvimento intersubjetivo entre pessoas de razão "sensível".

Ressalte-se, no entanto, que a razão nunca foi inocente em relação às suas contestaçóes que, ao longo da história, multiplicaram-se em esquemas estrategicamente formulados para desolá-la, principalmente calcados no esforço descomunal da gerência autorreferencial do poder que, sob a égide dos sistemas produtivos, recobrem a ordem global de investimentos multiplicadores do capital (mais dinheiro e poder e menos solidariedade). A condição erigida consiste em propiciar a derrocada dos sistemas da ação autônoma como, por exemplo, a escola, no sentido de neutralizá-los diante da grande condução de forças imperativas que impóem aos processos naturais da existência humana, fundadores do lócus de ação natural da vida, a própria desarmonia.

Desenvolver as intermediações das pretensóes constitutivas de verdades em crises tão profundas, tanto na Ciência, na sociedade, na política e na cultura, quanto nos recônditos das subjetividades (HABERMAS, 1987), de seus comportamentos e emoçóes, é um grande desafio para pensarmos na educação e seu potencial transformador e inerente à utopia da emancipação. As circunstâncias reais das exponenciais abrangências de desestruturação da cultura e do saber, sejam eles espontâneos ou formais, sofrem ainda mais ameaças em um contexto político de interesses ${ }^{5}$ finalistas. Tudo isso tem culminando em distúrbios do equilíbrio ecológico, em desrespeito às diferenças, em tensóes nas relaçóes internacionais, principalmente na iminência do surgimento de novos ditadores que, a exemplo de Hitler, ameaçam a democracia e a diplomacia nas Américas do Norte, Central, do Sul, na Europa, no Oriente Médio e na Ásia. Essa situação põe em xeque as condições políticas defensoras dos direitos universais, abertas às negociaçóes e

5 Habermas (1980) entende como “interesse" as necessidades que surgem a partir da consciência de conflitos, mesmo que por meio deles nem sempre seja possível acordos racionalmente justos na relação intersubjetiva. Nesse aspecto, a base para a satisfação subjetiva desiste de pensar nas coisas pelas vias da legitimação comum, ou seja, do que é válido, moral e eticamente, para consolidar planos estabelecidos que se desligam de ideais coletivos. A consciência de conflitos, nesse estágio, estabelece relaçóes de forças que substituem ações orientadas ao entendimento mútuo (acordo) pela ação guiada por fins (interesses). "O padrão da ação comunicativa dá lugar, então, a domínios de comportamentos politicamente relevantes, a aquele tipo de comportamento ao qual a competição de bens escassos fornece o modelo, isto é, a ação estratégica” (HABERMAS, 1980, p. 144). 
contrárias a qualquer tipo de atrofia à natureza e à condição digna da vida e dos direitos humanos.

Devido aos desígnios de várias envergaduras que desgastam as esperanças no futuro das crianças e no presente (quase estéril) da juventude, não é difícil encontrar, nos corredores das escolas brasileiras, educadores desolados, que, em muitas circunstâncias, parecem lançar, no silêncio atormentado das próprias inquietudes, dilemas que abalam o caráter existencialista da educação e da escola (sem partido?): que saberes podem sustentar a perspectiva de futuro? Como construir propostas educativas emancipatórias favoráveis ao presente? Como continuar acreditando que a educação é um dos fenômenos constituintes da liberdade, da solidariedade e da paz se os próprios professores se sentem ameaçados pela mesma descrença que assola a razão moderna, acuados, repreendidos e vítimas de violência física e moral?

\section{A educação no cenário da crise}

De acordo com Habermas (2000; 1999), o mundo vivido, outro fator constituinte da teoria da sociedade, é um lócus inventivo dos saberes naturais, em que os sujeitos desenvolvem sensações e apreendem os primeiros sentidos relacionados às suas visóes de mundo. Nesse horizonte nutrido pela força do existir, a construção social da consciência dá-se pelo aprendizado não teorizado, desenvolvido no seio da família e da comunidade. No contexto rico e intrínseco do mundo vivido, o senso de pertença, a identidade, os laços de afeto, os sentimentos, as relaçóes sociais, dentre outros fatores internos e condescendentes ao convívio em sociedade, são desenvolvidos espontaneamente no terreno natural de aprendizagens e rico de apreensóes de verdades. Nesse aspecto, as bases universais que constituem e são constituídas pelo mundo vivido são a cultura, a sociedade e a personalidade.

$\mathrm{O}$ contraponto do mundo vivido é o mundo dos sistemas, um arcabouço mantido pelos imperativos do dinheiro e do poder, cujas propensóes estratégicas insistem em dominar (colonizar) o mundo vivido, estagnando suas bases naturais e impedindo sua reprodução espontânea. Açóes sistêmicas sobre o mundo vivido podem ser sutis ou invisíveis e fazer parte, por exemplo, de propostas pedagógicas, conteúdos, didáticas, metodologias e avaliação escolar, sempre com o fito de neutralizar o potencial genuíno do mundo vivido a partir da razão instrumental sobre o saber, dos interesses capitalistas sobre a autonomia/liberdade e das açóes neoliberais sobre a economia. Desacoplar o mundo vivido das máculas do mundo sistêmico, racionalizar suas bases e equilibrar as duas plataformas constituintes da sociedade (mundo sistêmico e mundo vivido) é uma das utopias idealistas de Habermas (2005; 2001; 2000; 1999; 1990; 1989). 
Habermas (1980) refere que, por causa disso, as sociedades contemporâneas vivem uma profunda crise nas esferas públicas, na sociedade do trabalho e na ideia do Estado do bem-estar social que, por sua vez, desestrutura o mundo vivido. Para chegar a essa assertiva, o autor valeu-se de um excurso sobre o conceito de crise para dimensionar as profundas ambivalências que desarticulam os interstícios das formas de vida social trazidas, principalmente, pelas feiçóes do capitalismo pós-industrial, relacionado à luta pelo reducionismo do poder da razão, ao retorno do pensamento conservador e à ideia de que o fim da modernidade é como o fim da própria história. A principal marca desse contexto seria o processo de colonização do mundo vivido (dominação das formas de pensamento/ação autônomos), invadido pelas forças externas dos sistemas de poder do capital, o que traz inúmeras patologias coletivas que fazem a sociedade agonizar por causa dos céleres interesses da era pós-industrial.

Assim, o autor toma por empréstimo o conceito de crise das ciências médicas e o reordena em seu sentido original, baseado nas situaçóes de dependência a que o paciente se submete diante da relação com o médico, de quem fica completamente à mercê. Trazendo para as ciências sociais, Habermas (1980) articula o conceito de crise náo estritamente a uma relaçáo de dependência diante de uma realidade objetiva, mas à ideia de superação do quadro problemático. No entanto, a sensaçáo de incapacidade aparente, diante da resolução da crise, expóe o sujeito/sociedade a uma situação crucial: é preciso romper com determinados moldes presentes nas estruturas consolidadas pela cultura e/ou legitimadas pela política e pelas instituiçóes. "Conceber um processo enquanto uma crise significa tacitamente dar-lhe um significado normativo: a solução da crise concretiza uma libertação do sujeito colhido por ela" (HABERMAS, 1980, p. 12). Desse modo, o autor especifica que as crises atravessam a história das formaçóes sociais e exigem delas formas concretas de resolver os problemas, o que implica mudanças no status quo de suas próprias características.

$\mathrm{Na}$ fase do capitalismo avançado, em que as sociedades são regidas por relaçóes econômicas (investimento, produção, rendimento), as crises assumem, quase sempre, um fundo econômico, e o mercado é o núcleo dinâmico e motivador de crises cíclicas no mundo moderno. "A crise econômica resulta de contraditórios imperativos sistêmicos [dinheiro e poder] e ameaça a integração social" (HABERMAS, 1980, p. 44-5).

Nesse aspecto, as crises que se instalaram ao longo do processo, em que a razão moderna buscou firmar os passos da própria existência, assolaram muitas das esperanças que surgiram quando o homem percebeu que poderia ser mais. No entanto, mesmo estilhaçada, vítima de ataques formados por várias frentes alheias à sua missão, a razão ainda se mostra oportuna para a educação que (trans)forma, ou seja, que transcende as simples obviedades do conhecimento e da realidade, constituintes das imagens do mundo tradicional. 
Nesse tipo de educação, a razão é uma base de resistência pujante às invasões que a violam, porque, em seu âmago, pulsa uma multipolaridade que nega a iminência da unidimensionalidade da realidade, e visa ao desenvolvimento humano diante da (re)ligação dos saberes, a partir do resultado evolutivo da intersubjetividade em seu meio externo global. Ela continua a postos na vigília cósmica das descobertas, o que significa defender a evoluçáo social como desenvolvimento do pensamento inteligente (qualificação progressiva da cognição), contrária à fragmentação da consciência (manipulação ideológica que impede o esclarecimento da reificação).

A razão da educação emancipatória consiste no atributo da liberdade como condição universal da existência humana, devido aos valores éticos e aos processos autônomos de ser e de estar no mundo apreendido, como matriz de sociabilidade, como germe da comunicaçáo entre diferentes e como raiz constitutiva da democracia. Em Habermas (2001; 1999), a emancipação corresponde, sobretudo, ao aprimoramento da competência comunicativa que faz ascender, em sua progressão de socialização argumentativa dos sentidos sobre as coisas no mundo, a capacidade dos sujeitos linguísticos de se envolverem com a solidariedade de discursos coletivos, conteúdos significantes, relaçóes intersubjetivas e verdades compartilhadas. Nem toda educação, a priori, envolve-se com o compromisso da emancipaçáo, sobretudo quando seus fundamentos se erguem sobre interesses que náo se coadunam com a utopia emancipatória. Esse tipo de educação é oriunda e se mantém pelos domínios estratégicos do mundo sistêmico e seus arcabouços de poder, vigilância e disciplina.

Na contramão de domínios sistêmicos, a emancipação se constitui em espaços de valorização do esclarecimento, independentemente de contextos formais de legitimação do saber, como a escola. Sua constituição natural corresponde à própria base de naturalidade que arquiteta o mundo vivido e, em seu interior, a emancipação faz jus à própria essência da liberdade, isto é, torna-se fruto do próprio exercício do espírito liberto. Com base nesse pensamento, é de se supor que nem todo sujeito mantém, em suas referências de mundo, o caráter distintivo da liberdade. Esse percurso é feito através das seguintes simetrias: a) construção contínua da identidade e evolução cognitiva (subjetividade); b) reavaliação da natureza diversa e multiexpressiva dos saberes inatos da tradição, que envolvem valores éticos e morais (cultura); c) validade das normas consensuais e açóes conjuntas, redefinidas com a subjetividade e a cultura, por intermédio de competências argumentativas e sua capacidade de avaliar, reconstruir e reencaminhar verdades (sociedade).

Nesse sentido, a liberdade é uma condição imprescindível para a emancipação. Como nem todo contexto social, diferentemente de um mundo vivido racionalizado, favorece o desenvolvimento da liberdade, a emancipação não se torna uma utopia, mas uma representação imaginária. Privaçôes de liberdade fazem parte das sociedades disciplinares e de controle, que mantêm sob ameaças 
veladas, o entorno da subjetividade e o livre alcance do pensamento e das açóes. Por isso, as objeçóes contrárias à emancipação são ideológicas, e isso significa dizer que espaços privilegiados de aprendizagens, como a escola, não garantem, per si, a conquista da emancipação. Portanto, "a descentração da compreensão do mundo e a racionalidade do mundo da vida são condiçóes necessárias para uma sociedade emancipada" (HABERMAS, 1999, p. 110).

\section{A utopia da educação emancipatória}

Tendo em vista a utopia da educaçáo emancipatória, náo podemos aceitar a ideia de que a razão outorgou para si a suprema virtude da verdade irrefutável pelos próprios desdobramentos, já que, na base de seus fundamentos, reside a ambiência da dúvida, do questionamento e da argumentação. "A razão, no sentido forte do termo, traz, em si mesma, uma lógica atormentada que, a cada momento, presta contas do poder que exerce" (NOVAES, 1996, p. 11).

Em outros termos, a razão que constitui limites normativos para a própria expressividade não pode ser confundida com a razão logocêntrica, monopolizante, denunciada como uma hiper-razão aglutinadora de uma ordem defasada e, por isso, derrotada por defender seu projeto de modernidade que, na atualidade, esmoreceu e fez da sociedade um organismo sintomático, tristemente doente e, aparentemente, sem cura.

Na contramão do pessimismo, é difícil dar cabo a essas possibilidades, porque a razão sempre nutriu, em seu âmago, a paz e o conflito como contemplaçóes evolutivas sincrônicas, que desnudam a lógica de um paradoxo inerente aos estágios cognitivos, em processo de formação do pensamento e de pretensóes de validez convincentemente argumentadas. Dessa feita, na essência da razáo, germinam o diálogo, a escuta e o consenso, configurando as diferenças não como subtração, mas como enriquecimento cada vez maior para o progresso da liberdade do pensamento inteligente e da socialização da comunicação. Isso significa que a razão se predispôs ao acordo de cooperaçáo para operar a transcendência das cadeias que prendem os sentidos de ir além. Essa constituição de forças perfez as grandes linhas que marcam os caminhos cruzados da educação com a emancipação humana.

Nesse aspecto, a educação seria a razão em se fazendo ato e a alça intramodular da transmutação de uma realidade que se firmava como dada, imediata e inquestionável. Como a razão em ação de progressão, por meio de processos educativos erigidos pela conduta do "saber aberto", do conhecimento compartilhado como aprendizagem reflexiva, a educação assume um dos postos mais importantes para (trans)formar as limitaçóes da essência humana. Como 
um fenômeno renovador de mudanças pessoal e coletiva em que o projeto de transposiçáo da barbárie para a civilização se sustenta, a educação definhou-se no lado obscuro do "destino"; em outras palavras, da lógica atormentada da razão, atacada por infraçóes que provocaram grandes calamidades para sua ligação intrínseca com o esclarecimento, a liberdade, a autonomia e a emancipação.

$\mathrm{Na}$ história iluminada pela razão, o esclarecimento é a síntese de um processo ontológico, antropológico, psicológico e sociológico em que os seres humanos se situam desenvolvendo sinergias cognitivas, configuradas no poder transformador com que foi entregue à educação a missão de construir, conforme apregoa Habermas (2000), o sujeito renovado da modernidade.

Originalmente concebida como esclarecimento, a razão designou-se como a faculdade de julgar e de propiciar o entendimento. Conforme acentua Habermas (2004, p. 151), "a razão é a brasa sempre susceptível a se tornar chama”. Manter acesa a chama do esclarecimento, nos espaços questionadores da aprendizagem na escola, desde sempre, esteve medularmente vinculada aos desafios da educação. Com a prevalência do esclarecimento como princípio norteador da razáo emancipatória, a evolução social não só corresponde unicamente às esferas de interesses guiados pelas forças produtivas, como também brota fundamentalmente das estruturas processuais e normativas do saber racional e se constrói em constante revalidação.

\section{Desafios que se impõem à educação: o relativismo pedagógico}

$\mathrm{Na}$ conjuntura contemporânea, a educação tem se envolvido muito mais com a intraformação (não transcendência da realidade imediata) do que se preocupado com a totalidade do ser, em suas dimensóes ético-moral. E esta assertiva já não é tão desconhecida pela pedagogia e seus respectivos estudiosos.

O pensamento neopragmatista do desenvolvimento econômico esboça uma espécie de "ciência menor", que impóe um reducionismo ao saber e ao aprender e que torna a educação cada vez mais eficiente em sua condição de sustentabilidade, com uma identidade mercadológica transmutável e cada vez mais exigente para formar o "agente-celular" do mundo sistêmico e conduzir a realidade (im)posta.

Por essas vias, considerando as preocupaçóes ideológicas, no sentido de reduzir a complexidade e a eficácia da comunicação para a gestão de hegemonias econômicas e administrativas, a aparente irredutibilidade do Neopragmatismo, uma das mais poderosas correntes do pensamento ocidental, esforça-se para promover à educação uma redução de sua missão transformadora, que busca reificar o pensamento inteligente por intermédio da sobreposição da esfera cognitivo-instrumental à esfera cognitivo-comunicacional. Tudo isso tem culminado 
em um relativismo pedagógico que se solta de referências teóricas menos ostensivas à ordem vigente e vai se emoldurando aos desvelamentos sistemáticos de suas próprias crises. No esforço de buscar novas bases, parece valer todo tipo de modismo, o que suprime da educação sua capacidade autoinovadora e a renovaçáo de suas utopias originais, advindas do projeto moderno de mundo.

Teorias que não se encarrilham nas trilhas de interesses capitalistas (mundo sistêmico) parecem encarcerar-se diante da noção de funcionalidade, usabilidade e praticidade com que o poder utópico do esclarecimento e da emancipaçáo definha-se diante do que não se incorpora à natureza própria da dinâmica cêntrica e estratégica do capital. Nesse percalço, as proposiçóes abraçadas por teorias inusitadas na educação, como a gestáo por competências, por exemplo, levam para a escola concepçóes pluralizadas não como decorrência da diversidade, mas muito mais como respostas urgentes para readaptar as funções econômicas da educação.

Ao que tudo indica, na incessante procura por fundamentação que seja oportuna para as preocupaçóes da escola, qualquer proposição tem servido como alternativa para o quadro de insegurança e de nebulosidade educacional. Nos corredores, na sala de professores, na direção, nas reunióes pedagógicas e nos arredores da escola, correm modelos arquetipados por adaptaçóes precisas a formaçóes personalistas, sobre as quais ecoam palavras de ordem como "aprender a aprender", "aprender fazendo", "desenvolver habilidades", "incentivar competências", "preparar para o mercado de trabalho", "aluno-cliente", "aprendizagem prática", "qualidade total na educaçáo", "aprender brincando", "escola cidadâ", dentre outros slogans prototipados, que figuram em propostas pedagógicas como uma espécie de escudo que protege contra a falta de solução generalizada, fruto da crise que assola a educação.

Do lado dos pais, importam muito mais o volume de atividades que as crianças levam para casa, o número de jovens que são aprovados em exames préuniversitários, as atividades extracurriculares e os resultados exitosos em avaliaçóes mais quantitativas do que a discussão sobre as propostas pedagógicas das instituições de ensino. A obtenção de resultados conduz à validade do sistema por intermédio da mensuração e da verificação objetiva perpassada pelo controle do saber como "economia da técnica" ou, em outros termos, como racionalidade instrumental.

Grandes são os desafios que se impóem à educação diante desse panorama. Maior ainda é o cuidado em assumir atitudes precipitadas, como as que vivenciamos atualmente no Brasil, por exemplo, em que a necessidade de acesso à qualificação confunde-se com o popularismo do ensino técnico, notadamente na esfera profissionalizante: uma formação aligeirada, mais pragmática do que crítica, alicerçada no capital humano (valor econômico da educação) e na ciência aplicada (imediata) como o centrismo da formação do trabalhador em detrimento da formação do sujeito em suas várias dimensôes de complexidade. A expansão do ensino superior (cursos tecnólogos) e a reestruturação do ensino 
médio tangenciam interferências muito mais burguesas do que populares para reproduzir, a partir de si mesmos, o crescimento da instrução, com ideologias que supunham a generalização da escolarização formal muito mais na esfera privada do que na pública.

A maximização da qualificação para o trabalho e a orientação para conferir ao conhecimento valor de troca tornaram-se um componente essencial da ideologia neoliberal no cenário da era pós-industrial ou informacional. Nesse processo, a educação parece funcionar com uma dupla proposiçáo: como mecanismo que escamoteia as desigualdades erigidas pelo mercado e como aparato para multiplicar a mão de obra no cenário da modernização econômica e facilitar a formação técnico-instrumental.

\section{Considerações finais}

$\mathrm{Na}$ atual conjuntura educacional, fugir das perspectivas da modernização econômica é tão difícil - usando a metáfora de Habermas (2000) - quanto "jogar fora o bebê junto com a água do banho". A contundente metáfora é usada pelo autor para imprimir o sentido do que os homens fizeram com o projeto, ainda inacabado, da modernidade, isto é, descartaram-no sem mesmo realizá-lo em sua plenitude, cunhando o modismo intelectual da cultura "pós" - pós-modernismo, pós-humanismo, pós-liberalismo. O pensamento "pós" não se insurge como movimento de levante a uma nova proposta de humano, mas se instaura como âncora da atual face do neoconservadorismo ${ }^{6}$ e do neopragmatismo. Com o esforço de aparar as arestas das crises da modernidade, a pós-modernidade configura manifestaçóes empíricas como prioridades imediatas, propicia relaçóes objetuais com o mundo e, ao mesmo tempo, reafirma o próprio mundo interior como objeto (HABERMAS, 1990).

Podemos afirmar, com base nesse panorama, que o pensamento "pós" é um "aparadouro" de articulaçóes finalistas, através do qual a racionalidade instrumental é propensa a manifestar sua conduta de açóes, invadindo o que a modernidade tem de mais consistente: a racionalidade.

6 Habermas classifica como neoconservadores e anarquistas os que defendem o fim da modernidade e que se intitulam de "pós-modernos". De um lado, os neoconservadores dizem que a modernidade findouse em seu esgotamento cultural. De outro, os anarquistas apregoam a derrocada final da modernidade em seu todo. Sobre os anarquistas, Habermas (1990, p. 16) acrescenta: "também eles proclamam o fim do iluminismo e avançam para lá do horizonte da tradição da razão [...]. Mas, diferentemente do que acontece com os neoconservadores, os anarquistas despedem-se da modernidade em seu todo". 
É provável que um "adeus apressado à razão" tenha levado para a escola acontecimentos que colocaram os processos educativos no limite de suas possibilidades. Não é à toa, por exemplo, que a violência passou a ser o médium da força que impóe o código de conduta das relaçóes entre os agentes educativos e tornou-se a característica autolegitimada em muitas instituiçóes de ensino, sejam elas públicas ou privadas, de países pobres ou desenvolvidos. Essa realidade obriga professores e alunos a conviverem com o saber como a antítese de sua própria gênese, contrariamente à orientaçáo racional imbuída de inovar e de relacionar suas conexôes de sentido com a descoberta do novo - referência de coerência para a produção cultural do mundo vivido.

Horizonte das manifestações culturais desencadeadas pela existência humana, o mundo vivido não se reproduz sob o caráter nefasto de nenhuma forma de violência, visto que seu interior contém a própria educação por estar ligado aos fenômenos inter-relacionados às expressóes e às apreensóes da cultura humana. Assim, podemos supor que processos educativos que se exercem nas bases do mundo vivido assumem características da espontaneidade do aprendizado, a partir da herança de um dos seus potenciais de maior vulto, condicional ao esclarecimento da razão e ao entendimento mútuo: a comunicação.

A desenvoltura de açóes coordenadas ao entendimento, na perspectiva de situar o sujeito para compreender seu contexto, é o desafio didático-pedagógico da Educação. Assim, os aspectos produtivos em que os enlaces possibilitados pela educaçáo com o mundo vivido desencadeiam para a assunção da aprendizagem reflexiva (crítica) é o ponto principal da educação emancipatória: compreender os processos educativos como uma ação comunicativa (autônoma, esclarecedora, argumentativa, liberta e reflexiva).

Fundados em Habermas $(2001 ; 1999)$, podemos dizer que as possibilidades para que os processos educativos se tornem críticos e desenvolvidos com base nos princípios didático-pedagógicos da aprendizagem reflexiva não podem ser confundidas com a educação que não consegue se desvencilhar da razão centrada no sujeito objetual. Esse tipo de razão conduz a modelos pedagógicos que mantêm relaçóes de manipulação, e não, de solidariedade com a socialização do conhecimento.

Instrumentalizando o conhecimento, tal razão é cada vez mais eficiente para concretizar os determinismos nos quais os sujeitos têm que se enquadrar no interior dos processos educativos: a memorização em detrimento da reflexão, a verbalização, ao invés do debate, a individualização, em contraponto à

7 Habermas (1990, p. 15) afirma que o "adeus neoconservador à modernidade dirige-se, portanto, não à desenfreada dinâmica da modernização social, mas à capa exterior de uma autocompreensão cultural da modernidade que parece ter sido já ultrapassada”. 
intersubjetividade, e o planejamento tradicional do ensino contra um currículo mais flexível aos interesses e às necessidades dos alunos em sua perspectiva de vida. Em momentos de transiçáo importantes nas etapas educativas, especialmente no momento político por que passa o Brasil, a razão cêntrica agudiza a relaçáo entre sujeito cognoscente e objeto cognoscível e amplia as fendas da filosofia da consciência como o paradigma que torna o sujeito cada vez mais solitário por se condicionar a consumir instruçôes técnicas ao invés de aprendizagens reflexivas (produzir o conhecimento).

É nesse momento importante de definir a vida futura que estudantes impactam com mais força com o que se firmou como competitividade, um conceito estratégico da sociedade completamente administrada que aglutina uma noção de saber acumulativo, uma capacidade de estocar informaçóes como bens imprescindíveis ao sucesso profissional (ganhar cada vez mais dinheiro), o que torna a educação apenas o contrabalanço de uma reificação objetivista, orientada por normatizaçóes que distanciam a teoria da prática.

É por essas vias que o acesso ao conhecimento é muito mais um produto de consumo do que inovação possível, o que torna a escolha da profissáo um grande tormento que, muitas vezes, provoca transtornos entre o aluno e sua família, já que a base das decisóes parece não ser outra além das leis de mercado e do valor com que a economia confere importância/status à educação. Essa lógica prevalecente, também póe em xeque metodologias de ensino geridas por professores que mantêm imperturbável a convicção de que a educação é um processo, o saber, como pretensão válida, e a aprendizagem, como reflexão para além do imediatismo contundente e confluente da conjuntura sistêmica.

Levar para a cena o conceito comunicativo de razáo pode ampliar e recuperar os sentidos perdidos da teoria emancipatória da educação, cujo trajeto se faz pelo princípio da linguagem, promovendo a (re)construção das verdades (im)postas, por meio das infindáveis possibilidades com que a intersubjetividade redimensiona a relaçáo com o outro (solidariedade), com o conhecimento (esclarecimento), com o pensamento autônomo e a vida (emancipação) e com o acordo entre os diferentes (comunicação).

Habermas $(2001 ; 1999)$ entende que, se a comunicação não se dispuser a fomentar proferimentos advindos da reflexividade da argumentação e não pressupuser o direito que o outro usufrui no discurso, não poderá ser válida por contradizer o próprio princípio de ação. Para o autor, é a partir de tal lógica que a comunicação passa a ser racional. E como cada pessoa é dotada desse potencial, poderá dispor dele para (re)construir processos interativos e coletivos em seus respectivos planos de mundo. Nesse contexto, a escola, como espaço, o ato educativo, como processo interativo, a comunicaçáo, como método, e a aprendizagem, como síntese, são os recursos suficientes para continuar escrevendo 
a história moderna e seu esforço em abraçar a emancipação.

Nesse sentido, racionalizar ${ }^{8}$ as esferas de mundo por meio da comunicação é o intuito constitutivo e singular que Habermas $(2001$; 1999) defende como utopia evolutiva que fará do indivíduo solitário o sujeito da liberdade prometida ou, por que não dizer, o sujeito de uma nova "ágora". Tomamos por empréstimo a significação grega do termo ágora (praça, assembleia) para designar o espaço público da escola, e as açóes comunicativas (educativas) que se processam a partir de seu lócus, como uma esfera pública que pode ser estruturada a partir da concepção substantiva de cidadania e do compartilhamento de açóes evolutivas que favoreçam a democracia procedimental.

Por esse intermédio, a desinência ágora não faz parte do circuito fechado de açôes dúbias, por isso não entendemos que esse espaço simbólico, aludido aos processos educativos, restrinja-se a orientaçóes de açóes regidas a fins estratégicos. Ao contrário, a utopia da educação emancipatória vai buscando as fendas da razão instrumental, com o intuito de vislumbrar possibilidades de ação social na escola para desacoplar o diálogo com o saber das incoerências da pseudocomunicaçáo estabelecida pela normatividade técnica da educação. O privilégio da fala e do acordo, a interligaçáo das subjetividades, a solidariedade, a autonomia do pensamento e da argumentaçáo, a justeza das pretensôes de ação, dentre outras possibilidades que podem ser geridas pelo agir pedagógico, exemplificam formas de participar dos círculos da liberdade promovidos pela ágora em sala de aula, sobretudo para aqueles que acreditam em racionalidades abertas ao esclarecimento e à emancipação.

A liberdade é um princípio revolucionário, o que implica dizer que guarda uma dimensão política, mas que prepondera sobre si a autogestão subjetiva. É preciso, pois, predispor-se à liberdade como condição de sua possível existência. O terreno de uma nova "ágora" é inspirado em processos educativos fundados nas dimensôes multissetoriais (reconstrutivos/evolutivos) da liberdade interior, lançando luzes na perspectiva de um futuro em que a conquista coletiva da liberdade facilita o percurso social da emancipação.

Não pretendemos, com a ideia de emancipação, auferir ao racionalismo das açóes a responsabilidade de firmar a última verdade sobre as coisas no mundo, pois se assim o fosse, estaríamos decretando a hegemonia da ciência clássica e, com ela, a antítese da própria ideia de emancipação que pretendemos defender. Nosso discurso admite que as janelas que se abrem para a razão são esperançosas para que surjam ágoras no contexto da cultura planetária. Nessa complexa paisagem,

8 "Racionalizar significa aqui o cancelamento das relaçôes de coerção que, penetrando imperceptivelmente nas estruturas comunicativas impedem - através de bloqueios intrapsíquicos ou intrapessoais da comunicação - que os conflitos sejam afirmados e regulamentados de modo consensual" (HABERMAS, 1990, p. 34). 
a rearticulação da razão teria que se livrar das máculas deficitárias e emblemáticas que desatualizam os discursos tradicionais da pedagogia, fruto da queda de seus fundamentos normativos, e substanciar a ideia de processos educativos a partir de princípios racionais universais.

Percebemos que o passado educacional se recupera por meio de uma espécie de sentimento de "culpa" e da busca incessante por reversibilizar o sofrimento como também pela nostalgia ou pela ânsia de reconstrução racional da história. Destarte, é preciso assumir que a utopia é necessária como condição para a educação emancipatória, como enfrentamento do próprio passado e como desafio de futuro. É a isso que chamamos, no sentido de acreditar nas transformaçóes possíveis, de "re-avocar" a razão, isto é, de dar prosseguimento ao projeto moderno da educação, sem lhe conferir os mesmos perfis de seu tempo originário, mas a partir das interfaces multicomplexas da atualidade, sem fórmulas pré-concebidas, mas com fundamentos humanos bastante evidentes.

\section{Referências}

CASTELLS, M. A sociedade em rede - a era da informação: economia, sociedade e cultura. São Paulo: Paz e Terra, 1999, v. 1.

HABERMAS, J. Entre naturalismo e religiáo: estudos filosóficos. Rio de Janeiro: Tempo Brasileiro, 2007 (Coleção Biblioteca Colégio do Brasil, 14).

HABERMAS, J. Diagnósticos do tempo: seis ensaios. Rio de Janeiro: Tempo Brasileiro, 2005.

HABERMAS, J. A ética da discussáo e a questáo da verdade. Sáo Paulo: Martins Fontes, 2004a.

HABERMAS, J. Verdade e justificação: ensaios filosóficos. São Paulo: Loyola, 2004b. (Coleção Humanística).

HABERMAS, J. Consciência moral e agir comunicativo. Rio de Janeiro: Tempo Brasileiro, 2003 (Biblioteca Tempo Universitário, 84: Estudos Alemães).

HABERMAS, J. Teoria de la acción comunicativa: crítica de la razón funcionalista. Madrid: Taurus, 2001, v 2.

HABERMAS, J. O discurso filosófico da modernidade. Lisboa: Dom Quixote, 2000 .

HABERMAS, J. Teoria de la acción comunicativa: racionalidad de la acción y racionalización social. Madrid: Taurus, 1999, v. 1. 
HABERMAS, J. Técnica e ciência como ideologia. Lisboa: Edições 70, 1997. (Coleção Biblioteca de Filosofia).

HABERMAS, J. Pensamento pós-metafísico. Rio de Janeiro: Tempo Brasileiro, 1990.

HABERMAS, J. Para o uso pragmático, ético e moral da razão prática. Estudos Avançados. São Paulo: USP, v. 3, n 7, set./dez., 1989.

HABERMAS, J. Conhecimento e interesse. Rio de Janeiro: Zahar, 1987.

HABERMAS, J. A crise de legitimaçáo no capitalismo tardio. Rio de Janeiro: Tempo Brasileiro, 1980.

KANT, I. Resposta à pergunta: o que é esclarecimento? In: Textos seletos. 2 ed. Petrópolis: Vozes, 1985.

NOVAES, A. A crise da razão. São Paulo: Companhia das Letras, 1996. 